\title{
Molecular Characterization of Rabies Virus from Foxes in the Sultanate of Oman
}

\author{
Mohammad Hassan Body ${ }^{1, *}, \dagger$, Mohamed Sayed Ahmed ${ }^{1,2, \dagger}$, Hatim Hassan Eltahir ${ }^{1}$, \\ Mahir Ghareeb ALmaewaly ${ }^{1}$, Saif Alhabsi ${ }^{1}$ \\ ${ }^{1}$ Animal Health Research Centre, Ministry of Agriculture, Muscat, Sultanate of Oman \\ ${ }^{2}$ Department of Pathology, Faculty of Veterinary Medicine, Kafrelsheikh University, Kafrelsheikh, Egypt
}

Email address:

dr.bodymohammad@yahoo.com (M. H. Body)

${ }^{*}$ Corresponding author

$\dagger$ Mohammad Hassan Body and Mohamed Sayed Ahmed are co-first authors

\section{To cite this article:}

Mohammad Hassan Body, Mohamed Sayed Ahmed, Hatim Hassan Eltahir, Mahir Ghareeb ALmaewaly, Saif Alhabsi. Molecular Characterization of Rabies Virus from Foxes in the Sultanate of Oman. Animal and Veterinary Sciences. Vol. 6, No. 1, 2018 , pp. 17-20. doi: 10.11648/j.avs.20180601.14

Received: February 10, 2018; Accepted: March 9, 2018; Published: May 8, 2018

\begin{abstract}
Rabies was firstly recorded in Oman in August 1990, when a school boy had been bitten by a fox. Within a year, then the virus was recorded among red foxes (Vulpes vulpes). Unlike other developing countries, dog is not the usual agent of rabies transmission in Oman but fox considered the main reservoir (sylvatic transmission). The present study was Carried out to determine the molecular epidemiology of fox rabies virus in Oman. The nucleoprotein (N) genes were amplified from brain of three rabid foxes obtained during (2009-2012). The nucleotide sequences of the genes were subjected to molecular and phylogenic analysis. The phylogenic analysis was performed in relation to Omani foxes isolates and other sequences from the Saudi Arabia (isolated in 1987) available in the GenBank. Results indicated that only one genetic group of fox rabies virus appeared to be circulating in Oman since 1990. The study also showed that the recent isolate (2012) of Omani rabies virus from foxes is closely related (97\%) to those viruses isolated from foxes in Saudi Arabia. According to the obtained results, It is clear that since its first diagnosis in 1990 the rabies fox virus has not gone through significant virus variant in Oman, It seems that rabies is maintained endemically in Oman through wild foxes. In conclusion the findings reported here highlight the remarkable genetic stability of rabies virus.
\end{abstract}

Keywords: Rabies Virus, Fox, Genetic, Gen Bank, Oman

\section{Introduction}

Rabies virus has a single, negative-stranded RNA genome and consists of five structural proteins \{nucleoprotein $(\mathrm{N})$, matrix protein $(\mathrm{M})$, glycoprotein $(\mathrm{G})$, polymerase protein $(\mathrm{L})$ and nucleocapsid-associated phosphoprotein $(\mathrm{P})\}$ [20, 22, 25]. Prior to 1990, Oman was considered free of rabies. All suspected cases had been proven negative. Only two human positive cases were reported in 1983 and 1984, in Asian expatriate workers exposed to dog in their home countries, who died in Oman [2]. The first case of rabies in an Omani resident occurred in 1990 in a boy had been bitten by a fox [4]. Unlike other developing countries dog is not central to rabies transmission in Oman; fox considered the main reservoir (sylvatic transmission) of rabies $[2,10,12,14,15$, 19]. Fox (Vulpes vulpes) bites have been found associated with human and animal rabies in Oman since the first record in 1990 as $66 \%(99 / 150)$ of foxes were found positive for rabies [2]. In a retrospective study (1990-2000) in Oman it was found that fox rabies constituted $85 \%(182 / 215)$ of the total rabies positive samples and $67 \%(182 / 272)$ of cases submitted from foxes were confirmed. Moreover; 52\% $(12 / 23)$ of samples from dogs and $31 \%(9 / 29)$ from cats were also found positive for rabies during this period [2]. Red fox sightings are frequently reported in Oman living close to human settlements from the northern part of Oman (Al Hajar mountain rang) to the south-east coast [2, 15]. Therefore; determining the genotype of circulating fox rabies virus in 
Oman is important to understand its evolutionary relationship with local as well as neighboring countries to elucidate the dynamics of disease transmission, this is imperative for formulating preventive strategies.

\section{Materials and Methods}

For virus detection, either carcasses from foxes suspected or their chilled/frozen heads $(n=11)$ were submitted to the virology research section of AHRC center during (20062013). Brains were collected and immediately subjected to direct immunofluorescent test (FAT) using anti-rabies monoclonal globulin (Fujirebio Diagnosis Inc. 201 Great Valley parkway Malvern, PA 19355, USA) [23, 24]. Positive rabies samples were used for the RT-PCR. In this study 3 positive samples were further submitted to the GenBank for sequencing.

Total RNA was extracted from 0.2 to $0.5 \mathrm{~g}$ of brain tissue using QIA amp Viral RNA kit (QIAGEN. Germany) following the manufacture's protocol. PCR fragments were sequenced using the ABI PRISM BigDye terminator cycle sequencing kit (Perkin Elmer, USA). The phylogenetic tree was constructed with neighbor-joining method [18] in MEGA (Molecular Evolutionary Genetic Analysis) software [13].

\section{Results}

During the period of this study (11) suspected brain samples from foxes were submitted to the virology research center of AHRC in Oman. Ten out of the eleven brains were found positive by direct immuno-fluorescent test (FAT). The positive samples were subjected to reverse transcriptasepolymerase chain reaction (PT-PCR). Three positive samples were submitted to the GenBank under accession number (Kj018781) isolated in 2012, (Gu353155), (Gu353157) isolated in 2009 for gene sequence. The nucleotide sequence of the three genes together with two Omani fox isolates collected during $(1990,1991)$ were available in the GenBank and two foxes isolated in 1987 from Saudi Arabia (EU086163, U22481) were subjected to molecular and phylogenic analysis. The phylogenic analysis was performed in relation to Omani isolates and other sequences from Saudi Arabia, grouped in one cluster (Figure 1).

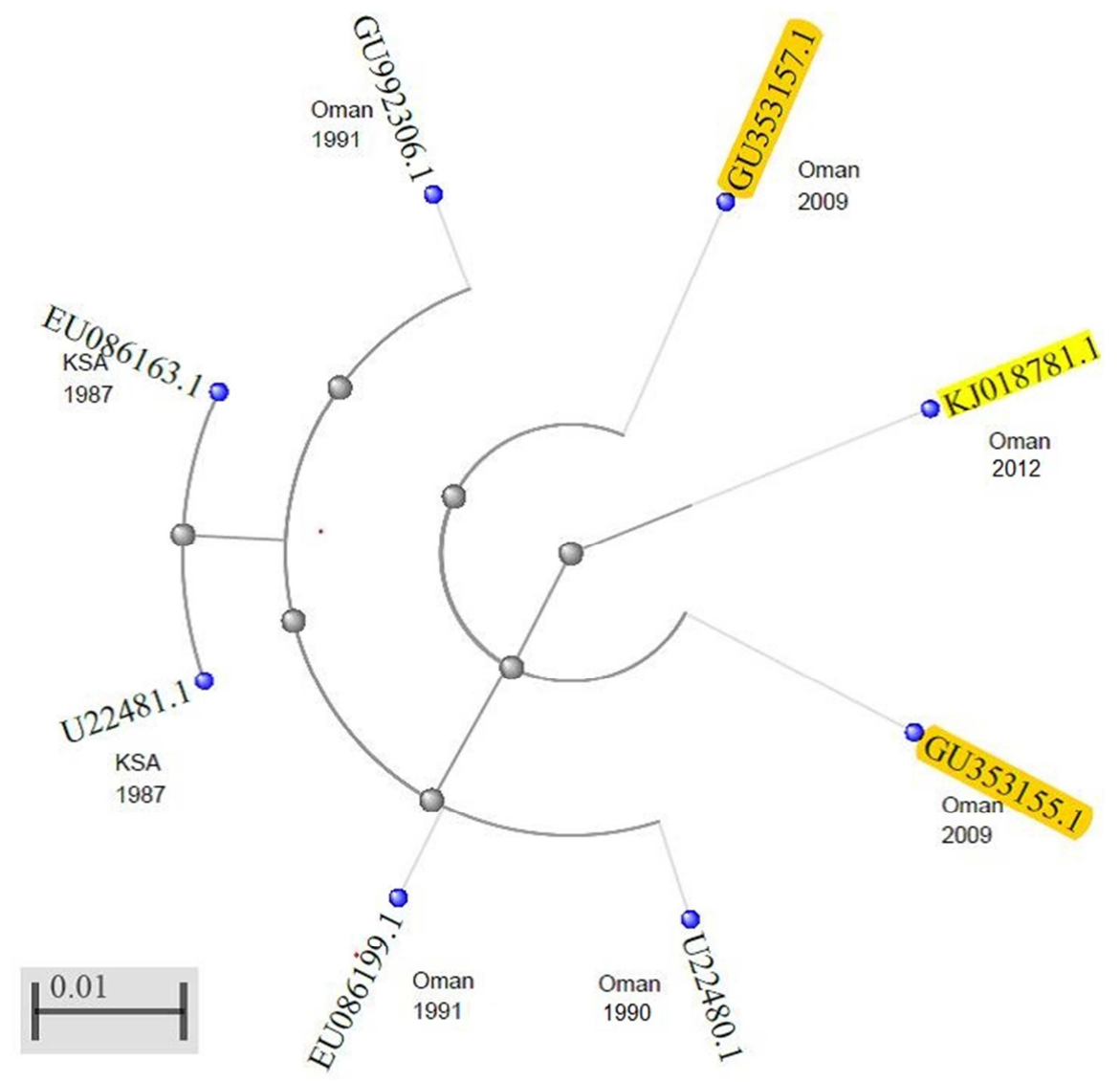

Figure 1. Phylogenetic trees based on the nucleotide sequences of the $N$ gene showing the relationship of recently fox rabies isolates in Oman with the fox isolates in 1990 to 1991 obtained from GenBank (EU086199, GU992306, U22480) and other isolate from Kingdom of Saudi Arabia (KSA).

The graphic distance showing these sequences producing significant alignments in comparison with the recently Omani fox isolate (2012) with $98-97 \%$ nucleotide homology (Table 1). Results showed that there were one genetic group of Fox rabies virus appeared to be circulating among the foxes in Oman from 1990 to 2012 with 97-98 \% homology, this study also indicated that the Omani fox rabies virus has a high degree of similarity (97\%) to the Saudi Arabia isolates (Table 1). 
Table 1. The results of GenBank graphic distance tree showing sequences producing significant alignments in comparison with KJ 018781.

\begin{tabular}{lllll}
\hline $\begin{array}{l}\text { Accession } \\
\text { number }\end{array}$ & $\begin{array}{l}\text { Year of } \\
\text { isolation }\end{array}$ & Country & Identity $\%$ & Species \\
\hline KJ018781 & 2012 & Oman & 100 & Fox \\
GU353157 & 2009 & Oman & 98 & Fox \\
GU353155 & 2009 & Oman & 98 & Fox \\
EU086199 & 1991 & Oman & 98 & Fox \\
GU992306 & 1991 & Oman & 97 & Fox \\
U22480 & 1990 & Oman & 97 & Fox \\
U22481 & 1987 & Oman & 97 & Fox \\
EUo86163 & 1987 & Oman & 97 & Fox \\
\hline
\end{tabular}

It is clear from the results that since its first diagnosis 1990, rabies virus has not gone significant variation, since there is no evidence of virus variant in other fox rabies in Oman and neighboring country, it seems that rabies is maintained endemically in Oman and the region through wild foxes.

\section{Discussion}

The nucleoprotein (N) gene is highly conserved among Lyssavirus genotype (rabies virus) and comparison of this gene has been employed in several epidemiological analyses and used extensively for genetic typing and evolutionary studies because of its relatively conserved variation among the reservoirassociated variant and geographic lineages [2, 3, 7, 8, 9]. Moreover; it also allows viral strains to be differentiated accurately by analyzing genetic differences within the gene [12, 17]. Many Workers used $(\mathrm{N})$ gene to study genetic analysis of rabies virus [16, 21]. A previous study in Oman Indicated that rabies virus isolated from different species and geographical areas has a high degree of similarity [6]. The results indicated that one genetic group of rabies virus appeared to be circulating among the foxes in Oman from 1990 to2012 with 97-98\% homology. The study also indicated that the Omani fox rabies virus is closely related (97\%) to the fox viruses isolated from Saudi Arabia which come in the same line with David et al 2000, who found that rabies virus from foxes from Oman, and Saudi Arabia were very closely related. It is clear from the results that since its first fox rabies diagnosis in Oman in 1990, the rabies virus has not gone significant variation from1990 till 2012 that of the one fox isolated from first outbreaks. A previous finding demonstrated a high degree of similarity between rabies virus isolated from different animal species in the Sultanate of Oman [6].

\section{Conclusion}

The findings reported here highlight the remarkable genetic stability of rabies virus.

\section{Acknowledgements}

This study was co-funded by the Agriculture and Fisheries Development Fund (AFDF) of Ministry of Agriculture and Fisheries, Sultanate of Oman. The funders had no role in study design, data collection and analysis, decision to publish, or preparation of the manuscript.

\section{References}

[1] ALismaaily, S. I., Tageldin, M. H., Body, M. H., and AL Habsy, S. (2002). retrospective studies of rabies in the Sultanate of Oman 1990-2000. Agric. Fish. Res. Bull. 2:2528.

[2] Anonymous (1992). Wijdlife rabies in Oman and the United Arab Emirates. Epidemiol. rec. 67:65-72.

[3] Arai, Y. T., Takahashi, H., Kameoka, Y., Shiino, T., Wimalaratne, O. and Lodmell, D. L. (2001). Characterization of Sri Lanka rabies virus isolates using nucleotide sequence analysis of nucleoprotein gene. Acta Virol. 45:327-333.

[4] Ata, F. A, Tageldin, M. H, Alsumry, H. S. and Alismaily, S. I. (1993). Rabies in the Sultanate of Oman. Vet Rec. 132:68-69.

[5] Batista, H. B., Mariano, P. C., Fernandes, M. E., Oliveira, R. N., Kawai, J. G., Carnieli,. J. r., and Roehe, P. M., (2015). Antigenic and Genetic Stability of Rabies Virus. Donnish Journal of General and Molecular Virology. 1:001-004.

[6] Body, M., ALrawhi, A., Hussain, M., Al Habsi, S., Awlad Wadir, A., Nirmala, S., Mohamed, S. A and Rajamony, S. (2014). Study on molecular characterization of rabies virus N gene segment from different animal species in the Sultanate of Oman. Journal of Veterinary Medicine and Animal Health 16(12):295-301.

[7] Boury, H., B. Kissi, N., Tordo, H., Badrane, H. and sacramento, D. (1995). Molecular epidemiology tools and phylogenetic analysis of bacteria and viruses with special emphasis on lyssaviruses. Prev. Vet. Med. 25:164-181.

[8] David, D., Yakobson, B., Smith, J. S. and Stram, Y. (2000). Molecular epidemiology of rabies virus isolates from Israel and other Middle- and Near-Eastern countries. J. Clin. Mirobiol. 38:755-762.

[9] Gunawardena, P. S., Marston, D. A., Ellis, R. J., Wise, E. L., Karawita, A. C., et al. (2016). Lyssavirus in Indian Flying Foxes, Sri Lanka. Emerg Infect Dis. 22:1456-1459.

[10] Hayman, D. T., Fooks, A. R., Marston, D. A. and Garcia, R. J. (2016). The Global Phylogeography of Lyssaviruses Challenging the 'Out of Africa' Hypothesis. PLoS Negl Trop Dis. 10(12).

[11] Hussain, M. H., Ward, M. P., Body, M., AL-Rawahi, A., wadir, A. A., AL-Habsi, S., Saqib, M., Ahmed, M. S. and Almaawali, M. G. (2013). Spatio-temporal pattern of sylvatic rabies in the Sultanate of Oman, 2006-2010., Prev. Vet. Med. 110:281-9.

[12] Johnson, N., McElhinney, L. M., Smith, J., Lowings, P. and Fooks, A. R. (2002). phylogenetic comparison of the genus Lyssavirus using distal coding sequences of the glycoprotein and nucleoprotein genes. Arch. Virol. 147:2111-2 3.

[13] Kumar, S., Tamura, K., Jakobsen, I. B. and Nei, M. (2001). MEGA2; molecular evolutionary genetics analysis software. Bioinformatics 17:1244-1245.

[14] Ministry of Health. Sultanate of Oman (1998). Rabies in Oman. Community Health and Disease Surveillance Newsletter II: 1-9. 
[15] Novelli, V. M. and Malankar. P. (1991). Epizootic of fox rabies in the Sultanate of oman. Trans. R. Trop. Med. Hyg. 85:543.

[16] Sacramento, D., Badrane, H., Bourhy, H. and Tordo, N. (1992). Molecular epidemiology of rabies virus in France; comparison with vaccine strain. J. Gen. Virol. 73:1149-58.

[17] Sadeuh-Mba, S. A., Momo, J. B., Besong, L., Loul, S. and Njouom, R. (2017). Molecular characterization and phylogenetic relatedness of dog-derived Rabies Viruses circulating in Cameroon between 2010 and 2016. PLoS Negl Trop Dis. 11(10).

[18] Saitou, N. and Nei, M. (1987). The neighbor-joining method; a new method for reconstructing phylogenetic trees. Mol. Biol. Evol. 4:406-425.

[19] Scrimgeour, E. M. and Mehta, F. R. (2001). Rabies in Oman; failed post exposure vaccination in lactating woman bitten by a fox. Int. J. Infec. Dis. 5:160-162.

[20] Traore, A., Picard-Meyer, E., Mauti, S., Biarnais, M., Balmer, O., et al. (2016). Molecular Characterization of Canine Rabies Virus, Mali, 2006-2013. Emerg Infect Dis. 22:866-870.
[21] Troupin, C., Dacheux, L., Tanguy, M., Sabeta, C., Blanc, H., et al. (2016). Large-Scale Phylogenomic Analysis Reveals the Complex Evolutionary History of Rabies Virus in Multiple Carnivore Hosts. PLoS Pathog. 12

[22] Tuvshintulga, B., Batmagnai, E., Bazarragchaa, E., Dulam, P., Sugar, S. and Battsetseg, B. (2015). Detection and molecular characterization of rabies virus in Mongolia during 20082010. Int J One Health. 1:26-31.

[23] Wiktor, T. J., Flamand, A. and Koprowski, H. (1980). Use of monoclonal antibodies in diagnosis of rabies virus infection and differentiation of rabies and rabies-related viruses. J. Virol. Method. 1(1):33-46.

[24] Wiktor, T. J. and Koprowski, H. (1978). Monoclonal antibodies against rabies virus produced by somatic cell hybridization: detection of antigenic variants. Proc.. Natl. Acad. Sci. 75:3938-3942.

[25] Wunner, W. H., Larson, J. K., Dietzschold, B. and Smith, C. L. (1988). The molecular biology of rabies viruses. Rev. Infect. 10(4):5771-5784. 